\title{
The quality of water served in the Orotta National Referral Hospital
}

\author{
Abraham Kebedom ' , Tadesse Teclebirhan ', Berhe Habtemicheal ${ }^{2}$, Eyob Habtemicheal ${ }^{\text {, }}$ \\ Jacob Mufunda ', and Andemariam Gebremicheal ${ }^{1}$. \\ Institutional affiliation of the authors \\ 'Orotta School of Medicine, class 2009 \\ ${ }^{2}$ Orotta National Medical Surgical Referral Hospital \\ Correspondence to be sent to akebedom@yahoo.com
}

Abstract

Background: The principal risks to human health associated with the consumption of unsafe drinking water are microbiological. According to the WHO and UNICEF report 2.6 billion people do not have access to good quality of water. About 1.1 billion people globally do not have access. About 2 million people mostly of less than 5 years children also die as a result of diarrheal diseases related to consumption of water that is microbiologically contaminated.

Objective: The objective of this study was to measure the quality of water served to the different sections of Orotta National Referral Hospital using WHO protocols.

Methods: Water samples were collected from different sources in the National Referral Orotta Hospital compound according to the WHO guidelines and the multi-tube method or most probable number method was used for the microbiological count.

Results: The findings from the study showed that some of the samples of water from National Referral Pediatric Hospital, and National Medical and Surgical Referral Hospital reservoirs did not meet some of the WHO guidelines for safe drinking water.

Conclusion and recommendations: The water contamination emanated from the reservoirs of the Orotta Hospital, because the samples taken as a control from outside the Hospital compound were free of contamination. Water reservoirs should be washed on regular basis. Chlorination and other treatment modalities for the water in the reservoir should also be considered and applied. Water quality surveillance should be done several times in a year not only just once.

\section{Introduction}

Access to safe drinking water is one of the basic human rights and is enormously crucial to health. Drinking water quality is a public health concern equally for developed and developing countries. For a nation to maintain optimal health and development there has to be continual supply of safe drinking water to its population ${ }^{1}$.

According to the WHO guideline values for bacteriological quality, all water intended for drinking, treated water entering the distribution system, and treated water in the distribution system should not have detectable levels of Escherichia coli (E. coli) or thermotolerant coliform bacteria in any $100 \mathrm{ml}$ of the water sample ${ }^{2}$. Immediate investigative action must be taken if either E. coli or total coliform bacteria are detected. The minimum action in the case of total coliform bacteria is repeat sampling; if these bacteria are detected in the repeat sample, the cause must be determined by immediate further investigation ${ }^{1,2}$.

According to the presence of thermotolerant (fecal) coliform or E.coli, samples could be classified on color code scheme. A count of $0 \mathrm{E}$. coli per $100 \mathrm{ml}$ of sample in conformity with the WHO guidelines is as category A (blue), 0-10 E. coli as category B (green) with low risk, 10-100 E.coli as category C (yellow) with intermediate risk, 100-1000 E. coli as category D (orange) with high risk, and $>1000 \mathrm{E}$. coli as category $\mathrm{E}$ (red) with very high risk for drinking water ${ }^{1}$.

Safe drinking water is the water that does not pose significant risk to health over a lifetime of consumption and is suitable for all usual domestic purposes, including personal hygiene. ' Unsafe drinking water is a source of wide spread water borne diseases, be a recreational, agricultural or drinking, in a direct or indirect way have an effect on the human health'.

The principal risks to human health associated with the consumption of unsafe drinking water are microbiological. Drinking-water is a vehicle for disease transmission.Someagentsmaybetransmitted primarily from person to person and, for bacteria capable of multiplication in food, foodborne transmission may be more important than transmission by drinking-water. Other agents, however, such as Salmonella typhi, Vibrio cholerae, Giardia lamblia and hepatitis A virus, are frequently transmitted via contaminated drinkingwater'.

Drinking water could be contaminated at any point from the source up to the level of consumers ${ }^{3}$. The contaminants of water could be classified as biological, chemical, and radiological'. According to the WHO and UNICEF report 2.6 billion people do not have access to acceptable sanitation facility and about 1.1 billion people globally do not access to improved water source receive improved water source. About 2 million people mostly under 5 year children die as result of diarrheal diseases ${ }^{2}$.

Public water systems have to undergo through a regular testing to ensure the safety of water. Since it is almost impractical to test for the wide variety of 
pathogens in the water on regular basis for it is being very expensive, time consuming, water contamination is measured using bacteria which normally constitute flora in the intestinal tracts of warm blooded animals referred to as indicator bacteria ${ }^{4}$. The significance of coliform presence in drinking water implies contamination and /or animal feces ${ }^{1,4-6}$.

Total coliform bacteria are commonly found in the environment (e.g., soil or vegetation) and are generally harmless. If only total coliform bacteria are detected in drinking water, the source is probably environmental. However, if environmental contamination can enter the system, there may also be a way for pathogens to enter the system. Therefore, it is important to find the source and resolve the problem ${ }^{5}$. Fecal coliform bacteria are a sub-group of total coliform bacteria. They appear in great quantities in the intestines and feces of people and animals. The presence of fecal coliform in a drinking water sample often indicates recent fecal contamination - meaning that there is a greater risk that pathogens are present than if only total coliform bacteria is detected ${ }^{5}$. E. coli is a sub-group of the fecal coliform group. Most E. coli bacteria are harmless and are found in great quantities in the intestines of people and warm-blooded animals. Some strains, however, can cause illness. The presence of E. coli in a drinking water sample almost always indicates recent fecal contamination - meaning there is a greater risk that pathogens are present ${ }^{1}$.

In Eritrea $90 \%$ of the urban and about $70 \%$ of the rural population have access to safe drinking water supply. A nationwide survey done in 2006 showed that $60.5 \%$ of the test results from protected water sources revealed absence of bacterial contamination, 39.5\% had contamination, where as one third of the samples from the water trucks were safe and two thirds of the samples indicated contamination ${ }^{7}$.

The quality of water supplied to different sections of Orotta National Referral Hospital has not been systematically studied. The objective of this study is to measure the quality of water using WHO protocols.

\section{Materials and Methods}

This study is prospective study which examined samples of water which were collected from eight different sites within the Orotta National Referral Hospital complex according to the WHO of collection procedure standards. Two samples of water were collected from each of the eight sites with the first sample subjected to biological analysis whereas the second sample was for physicochemical analysis.

Microbiological and chemical analyses were done. The microbiological component had the qualitative and quantitative enumeration of the organisms identified. The principal methods used in the isolation of indicator organisms from water used by the WHO are the membrane-filtration (MF) method, the multiple-tube (MT) or most probable number (MPN) method and presence-absence test1. In this study the multiple tube method or most probable number was employed.

\section{Laboratory confirmation of E. coli:}

In the traditional method for detecting E. coli the water sample was inoculated to the laurly sulphate tryptose lactose broth for 24 hours in the presumptive test. E. coli ferments lactose to produce acids and gases. A positive test was production of gas and had to proceed to the next step to confirm that the gas producing organism in the water was E.coli. The sample from the positive presumptive test was inoculated to a selective culture media, brilliant green lactose broth and inoculated for 24 hours. After an appropriate incubation time, the tubes were examined for gas formation as before. The most probable number (MPN) of bacteria present estimated from the number of tubes inoculated and the number of positive tubes obtained in the confirmatory test, using specially devised statistical tables ${ }^{4}$. Then culture media with a special broth selective for individual or group of bacteria were prepared and allowed to grow for identification by biochemical identification.

\section{Results}

\section{Microbiological Examination}

The following sampling sites are coded National Referral Pediatric Hospital as 01, National Referral Medical Surgical Hospital, non kitchen water as 02, National Referral Medical Surgical Hospital, kitchen water as 03, from the truck directly as 03, Maternity Hospital as 04, Gynecology Hospital as 05, Nursing School kitchen water as 06, National Blood Bank, direct municipality water as 07 , and Nursing School, kitchen water, Bladder water as 08 .

The first sample of water from sites 01,02 and 03 were all significantly contaminated especially site 01 (Table 1)

\begin{tabular}{|c|c|c|c|}
\hline Parameters & Res & & \\
\hline & 01 & 02 & 03 \\
\hline Total coliforms $/ 100 \mathrm{ml}$ at $370 \mathrm{C}$ & 15000 & 1100 & 1100 \\
\hline Feacal colifroms $/ 100 \mathrm{ml}$ at $440 \mathrm{C}$ & 15000 & 1100 & 1100 \\
\hline E. coli/ $100 \mathrm{ml}$ at $440 \mathrm{C}$ & 15000 & 1100 & 1100 \\
\hline $\begin{array}{l}\text { Shigella, salmonella, staphylocc } \\
\text { cells were not isolated from the } \\
\text { where as Streptococcus group } \\
\text { samples coded from } 02 \text { and } 03 \\
\text { fecal contamination. }\end{array}$ & $\begin{array}{l}\text { us Aure } \\
\text { bove s } \\
\text { was i } \\
\text { hich sic }\end{array}$ & $\begin{array}{l}\text { us and } \\
\text { mpling } \\
\text { olated } \\
\text { nify a }\end{array}$ & $\begin{array}{l}\text { yeast } \\
\text { sites } \\
\text { from } \\
\text { ecent }\end{array}$ \\
\hline
\end{tabular}

The physic-chemical properties 
IOURNAL OF ERITREAN MEDICAL ASSOCIATION JEMA

\begin{tabular}{|l|c|c|c|}
\hline $\begin{array}{l}\text { Table 2: Physicochemical Analyses for the first } \\
\text { sample }\end{array}$ \\
\hline Parameter & \multicolumn{3}{l|}{ Results } \\
\hline & 01 & 02 & 03 \\
\hline $\begin{array}{l}\text { Total hardness as caco3 } \\
\text { (ppm) }\end{array}$ & 108 & 608 & 110 \\
\hline $\begin{array}{l}\text { Calcium hardness as caco3 } \\
\text { (ppm) }\end{array}$ & 70 & 330 & 74 \\
\hline Magnesium hardness (ppm) & 38 & 278 & 36 \\
\hline Total alkalinity(ppm) & 26 & 116 & 32 \\
\hline $\begin{array}{l}\text { Chloride (cl-) concentration } \\
\text { (ppm) }\end{array}$ & 7.09 & 14.18 & 7.09 \\
\hline Total dissolved solids (ppm) & 120 & 840 & 80 \\
\hline PH at 200 C & 7.91 & 7.59 & 7.98 \\
\hline Conductivity $(\mu / \mathrm{cm})$ & 251 & 1154 & 237 \\
\hline Calcium as ca++ in ppm & 28.056 & 132.264 & 29.659 \\
\hline Magnesium as Mg++ in ppm & 9.234 & 67.554 & 8.784 \\
\hline
\end{tabular}

\begin{tabular}{|l|l|l|l|l|l|l|l|l|}
\hline $\begin{array}{l}\text { Chloride } \\
\text { (cl-) } \\
\text { concen } \\
\text { tration } \\
\text { (ppm) }\end{array}$ & 7.09 & 21.27 & 7.09 & 7.09 & 7.09 & 7.09 & 7.09 & 14.18 \\
\hline $\begin{array}{l}\text { Total } \\
\text { dissolve } \\
\text { solids } \\
\text { (ppm) }\end{array}$ & 200 & 980 & 180 & 160 & 80 & 160 & 120 & 60 \\
\hline $\begin{array}{l}\text { PH at } \\
\text { 200C }\end{array}$ & 7.44 & 7.51 & 7.44 & 7.5 & 6.84 & 7.12 & 7.68 & 7.53 \\
\hline $\begin{array}{l}\text { Condu } \\
\text { ctivity } \\
\text { ( } \mu \text { /cm) }\end{array}$ & 232 & 1121 & 250 & 232 & 232 & 225 & 234 & 235 \\
\hline $\begin{array}{l}\text { Calcium } \\
\text { as ca++ } \\
\text { in ppm }\end{array}$ & 29.66 & 131.47 & 28.06 & 28.06 & 28.06 & 26.45 & 32.06 & 28.86 \\
\hline $\begin{array}{l}\text { Magne } \\
\text { sium as } \\
\text { Mg++ } \\
\text { in ppm }\end{array}$ & 7.29 & 66.09 & 7.29 & 7.29 & 6.8 & 6.32 & 5.83 & 8.75 \\
\hline
\end{tabular}

Table 3: Microbiological analysis for the second sample

\begin{tabular}{|l|c|c|c|c|c|c|c|c|}
\hline \multicolumn{1}{|c|}{ Parameters } & \multicolumn{7}{|c|}{ Results } \\
\hline & 01 & 02 & 03 & 04 & 05 & 06 & 07 & 08 \\
\hline $\begin{array}{l}\text { Total coliforms/100ml at } \\
370 \mathrm{C}\end{array}$ & 23 & 48 & 23 & 0 & 0 & 0 & 0 & 0 \\
\hline $\begin{array}{l}\text { Feacal colifroms/100ml at } \\
\text { 440 C }\end{array}$ & 23 & 48 & 23 & 0 & 0 & 0 & 0 & 0 \\
\hline E. coli//100ml at 440 C & 23 & 48 & 0 & 0 & 0 & 0 & 0 & 0 \\
\hline $\begin{array}{l}\text { Shigella, salmonella, staphylococcus Aureus, streptococcus group D, } \\
\text { and yeast cells were not isolated from the above 8 sampling sites. }\end{array}$ \\
\hline
\end{tabular}

Table 5: Microbiological analysis for the third sample

\begin{tabular}{|l|l|l|l|l|}
\hline \multirow{2}{*}{ Parameter } & \multicolumn{4}{|l|}{ Results } \\
\cline { 2 - 5 } & 01 & 02 & 03 & $03^{*}$ \\
\hline Total coliforms/100ml at 370 C & 7 & 150 & 0 & 0 \\
\hline Feacal colifroms/100ml at 440 C & 7 & 150 & 0 & 0 \\
\hline E. coli/100ml at 440 C & 7 & 150 & 0 & 0 \\
\hline
\end{tabular}

Shigella, salmonella, staphylococcus Aureus, streptococcus group D, and yeast cells were not isolated from the above sampling sites. The bacterial organism, E. coli was isolated from the sample coded 03 on biochemical analysis.

Table 4: Physicochemical Analysis for the second sample

\begin{tabular}{|l|c|c|c|c|c|c|c|c|}
\hline Para & \multicolumn{7}{|c|}{ Results } \\
\cline { 2 - 8 } meters & 01 & 02 & 03 & 04 & 05 & 06 & 07 & 08 \\
\hline $\begin{array}{l}\text { Total } \\
\text { hard } \\
\text { ness as } \\
\text { cac03 } \\
\text { (ppm) }\end{array}$ & 104 & 600 & 100 & 100 & 98 & 92 & 104 & 108 \\
\hline $\begin{array}{l}\text { Calcium } \\
\text { hardness } \\
\text { as cac03 } \\
\text { (ppm) }\end{array}$ & 74 & 328 & 70 & 72 & 70 & 66 & 80 & 72 \\
\hline $\begin{array}{l}\text { Magne } \\
\text { sium } \\
\text { hardness } \\
\text { (ppm) }\end{array}$ & 30 & 272 & 30 & 28 & 28 & 26 & 24 & 36 \\
\hline $\begin{array}{l}\text { Total } \\
\text { alkalinity } \\
\text { (ppm) }\end{array}$ & 32 & 114 & 34 & 34 & 36 & 38 & 40 & 40 \\
\hline
\end{tabular}

Table 6: Potability Report

\begin{tabular}{|c|c|c|c|c|c|}
\hline $\begin{array}{l}\text { Name of } \\
\text { Institution }\end{array}$ & Type of samples & $\begin{array}{l}\text { Co } \\
\text { de }\end{array}$ & Date & $\begin{array}{l}\text { Bacterio } \\
\text { logy }\end{array}$ & $\begin{array}{l}\text { Che } \\
\text { mic } \\
\text { al }\end{array}$ \\
\hline $\begin{array}{l}\text { Pediatric } \\
\text { hospital }\end{array}$ & $\begin{array}{l}\text { Tap water from } \\
\text { the reservoir after } \\
\text { reaching high } \\
\text { above the } \\
\text { building but } \\
\text { its source is } \\
\text { underground } \\
\text { reservoir } \\
\text { connected to the } \\
\text { municipality main } \\
\text { line }\end{array}$ & 01 & $\begin{array}{l}22 / 01 / 08 \\
28 / 02 / 08 \\
10 / 03 / 08\end{array}$ & $\begin{array}{l}\text { All } \\
\text { types of } \\
\text { coliform } \\
\text { have } \\
\text { been } \\
\text { isolated } \\
\text { Not } \\
\text { potable }\end{array}$ & $\begin{array}{l}\text { pota } \\
\text { ble }\end{array}$ \\
\hline
\end{tabular}




\begin{tabular}{|c|c|c|c|c|c|}
\hline $\begin{array}{l}\text { Medical } \\
\text { surgical } \\
\text { hospital }\end{array}$ & $\begin{array}{l}\text { Drill water, water } \\
\text { found close to the } \\
\text { pediatric hospital. } \\
\text { The water is } \\
\text { pumped through } \\
\text { electric Pump to } \\
\text { medical surgical } \\
\text { campus garden. } \\
\text { Some times this } \\
\text { water is used by } \\
\text { outpatients, and } \\
\text { kitchen purposes. }\end{array}$ & 02 & $\begin{array}{l}22 / 01 / 08 \\
28 / 02 / 08 \\
10 / 03 / 08\end{array}$ & $\begin{array}{l}\text { All } \\
\text { types of } \\
\text { coliform } \\
\text { have } \\
\text { been } \\
\text { isolated } \\
\text { Not } \\
\text { potable }\end{array}$ & $\begin{array}{l}\text { Not } \\
\text { pota } \\
\text { ble }\end{array}$ \\
\hline $\begin{array}{l}\text { Medical } \\
\text { surgical } \\
\text { hospital }\end{array}$ & $\begin{array}{l}\text { Water is pumped } \\
\text { into the } 500 \\
\text { Meter cube, } \\
\text { capacity reservoir } \\
\text { built at the slope } \\
\text { of forto. }\end{array}$ & 03 & $\begin{array}{l}22 / 01 / 08 \\
28 / 02 / 08 \\
10 / 03 / 08\end{array}$ & $\begin{array}{l}\text { The sam } \\
\text { ples } \\
\text { show } \\
\text { coli } \\
\text { forms } \\
\text { Not } \\
\text { potable }\end{array}$ & $\begin{array}{l}\text { pot } \\
\text { able }\end{array}$ \\
\hline $\begin{array}{l}\text { MCH } \\
\text { Maternity } \\
\text { hospital }\end{array}$ & $\begin{array}{l}\text { The reservoir is } \\
\text { built at the slope } \\
\text { Of forto close to } \\
\text { residents, from } \\
\text { this water reaches } \\
\text { the hospital } \\
\text { gravitationally. }\end{array}$ & 04 & $28 / 02 / 08$ & potable & $\begin{array}{l}\text { pota } \\
\text { ble }\end{array}$ \\
\hline $\begin{array}{l}\text { Gyne } \\
\text { cology } \\
\text { hospital }\end{array}$ & $\begin{array}{l}\text { Direct } \\
\text { municipality } \\
\text { water in their } \\
\text { own reservoir. }\end{array}$ & 05 & $28 / 02 / 08$ & potable & $\begin{array}{l}\text { pota } \\
\text { ble }\end{array}$ \\
\hline $\begin{array}{l}\text { College of } \\
\text { Nursing } \\
\text { and health } \\
\text { technology }\end{array}$ & $\begin{array}{l}\text { Municipality } \\
\text { water in their own } \\
\text { reservoir. }\end{array}$ & 06 & $28 / 02 / 08$ & potable & $\begin{array}{l}\text { pota } \\
\text { ble }\end{array}$ \\
\hline $\begin{array}{l}\text { Water truck } \\
\text { plate N0.3- } \\
04287 \\
\text { with a } \\
\text { capacity of } \\
18.5 \text { cubic } \\
\text { meter. }\end{array}$ & $\begin{array}{l}\text { Water hydrant } \\
\text { near the coca- } \\
\text { cola factory }\end{array}$ & $03^{*}$ & $10 / 3 / 08$ & potable & $\begin{array}{l}\text { pota } \\
\text { ble }\end{array}$ \\
\hline $\begin{array}{l}\text { Collage of } \\
\text { nursing } \\
\text { and health } \\
\text { technology }\end{array}$ & $\begin{array}{l}\text { Water bladder } \\
\text { with capacity } \\
\text { of } 50 \text { barrels is } \\
\text { permanently laid } \\
\text { above a clean } \\
\text { area. }\end{array}$ & 08 & $10 / 3 / 08$ & potable & $\begin{array}{l}\text { pota } \\
\text { ble }\end{array}$ \\
\hline $\begin{array}{l}\text { National } \\
\text { Blood } \\
\text { Bank }\end{array}$ & $\begin{array}{l}\text { Municipality } \\
\text { water pipe } \\
\text { entering the } \\
\text { National Blood } \\
\text { bank main } \\
\text { building. Before } \\
\text { entering a } \\
\text { reservoir. }\end{array}$ & 07 & $10 / 3 / 08$ & potable & $\begin{array}{l}\text { pota } \\
\text { ble }\end{array}$ \\
\hline
\end{tabular}

\section{Discussion}

The Orotta National Referral Hospital has several sources of drinking water and water for other purposes.
Public water sources have to undergo through regular tests to ensure the safety of drinking water. The focus of this study was on the biological component of water contaminants which could be introduced at any point from its source to the level of individual reservoir in households or handlers. There was water sampling conducted on annula basis. Some samples of water had microbiological contamination. There is need to conduct water sampling as per WHO guidline in order to prevent water borne infections spreading to consumers of the contaminated water.

According to the WHO guideline values for bacteriological quality, all water intended for drinking, treated water entering the distribution system, and treated water in the distribution system should not be detected any by any E.coli or thermotolerant coliform bacteria in any $100 \mathrm{ml}$ of sample. Immediate investigative action must be taken if either $\mathrm{E}$. coli or total coliform bacteria are detected. The minimum action in the case of total coliform bacteria is repeat sampling; if these bacteria are detected in the repeat sample, the cause must be determined by immediate further investigation'. According to the presence of thermotolerant (fecal) coliform or E.coli, samples could be classified on color code scheme. A count of $0 \mathrm{E}$. coli per $100 \mathrm{ml}$ of sample in conformity with the WHO guidelines is as category A (blue), 0-10 E. coli as category B (green) with low risk, 10-100 E.coli as category C (yellow) with intermediate risk, 100-1000 E. coli as category $\mathrm{D}$ (orange) with high risk, and $>1000 \mathrm{E}$. coli as category $E$ (red) with very high risk for drinking water'.

The first set of tests was done as a yearly surveillance by the environmental health unit of the Orotta Hospital and the level of contamination was very high. According to the classification and color coded scheme for the thermotolerant E. coli it was category $\mathrm{E}$ red colored which was very high risk for drinking. Streptococcus group D was also identified in samples coded 02 and 03 which signified recent contamination. Then in the second round we increased the number of samples from different reservoirs in the Orotta Hospital compound and as a control outside from the hospital compound to study their safety. After the second results there were differences with the first results for the first 3 samples which were previously positive. Variation in microbilogical test results of water sampling has been frequently reported finding making the quality of water fluctuating periodically hence the need for point of use treatment ${ }^{8,9}$.

The main reservoir of Orotta Medical Surgical National Referral Hospital was found to be free of thermotolerant coliforms even though positive for feacal coliforms. The first five samples during the second round of tests were reached the laboratory 3 hours after their collection which may have contributed to the low count for the second time results.

In the third sample test the results showed that the contamination level is low and similar to the second sample tests but the kitchen water from the Orotta Medical Surgical National Referral Hospital were negative for the traditional methods of identification 
even though it had shown the growth of $E$. coli on biochemical analysis. The values of sample 02 were relatively elevated in respect to the second set of tests.

During the third sample tests the water from Orotta Medical and Surgical National Referral Hospital got free based on the traditional method of identification. This could be explained that one day before the sampling date the remaining stagnant water at the bottom of the reservoir was eliminated.

\section{Conclusion and recommendation}

From this study it can be concluded that the biological quality of water of the National Referral Pediatric Hospital, and National Medical and Surgical Referral Hospital reservoirs did not meet the WHO guidelines for safe drinking water. Reservoirs should be washed on regular basis and underground reservoirs are prone to sanitary contamination and inconvenient to wash. It is advisable to change those underground and old reservoirs of Orotta National Referral Pediatric Hospital to another type of reservoir above the ground. In such situations chlorination of the reservoir should also be considered. There is also a possibility that the water trucks contaminating the reservoir, so the environmental health unit of Orotta Hospital had to control these water trucks strictly. The drilled water meant for garden purpose should not be used for kitchen purposes under any conditions and the screw for the tap should be held by the gardeners. Water surveillance should be done several times in a year not only just once as the current practice. The response to such alarming problems should be an emergency, since a hospital meant to treat patients is actually a source of diseases.

\section{References}

1. Drechsel P, Keraita B, Amoah P, Abaidoo RC, Raschid-Sally $L$, Bahri A. Reducing health risks from wastewater use in urban and peri-urban sub-Saharan Africa: applying the 2006 WHO guidelines. Water Sci Technol. 2008;57:1461-9

2. Sobsey MD, Bartram S.Water quality and health in the new millennium: the role of the World Health Organization Guidelines for Drinking-Water Quality. Forum Nutr. 2003;56:396-40

3. Clasen TF, Bastable A. Faecal contamination of drinking water during collection and household storage: the need to extend protection to the point of use. J Water Health. 2003 Sep;1(3):109-15.

4. Graf J, Meierhofer R, Wegelin M, Mosler HJ. Water disinfection and hygiene behaviour in an urban slum in Kenya: impact on childhood diarrhoea and influence of beliefs. Int J Environ Health Res. 2008 Oct;18(5):335-55.

5. Carr RM, Blumenthal UJ, Mara DD. Guidelines for the safe use of wastewater in agriculture: revisiting WHO guidelines. World Health Organization, Geneva, Switzerland.

6. Fawell J, Nieuwenhuijsen MJ. Contaminants in drinking water. Br Med Bull. 2003;68:199-208Jakopanec I, Borgen K, Vold L, Lund H, Forseth T, Hannula R, Nygård K. A large waterborne outbreak of campylobacteriosis in Norway: the need to focus on distribution system safety. BMC Infect Dis. 2008 Sep 24;8:128.

7. Srikanth R, NaikDPrevalence of Giardiasis due to wastewater reuse for agriculture in the suburbs of Asmara City, Eritrea. Int J Environ Health Res. 2004 Feb;14(1):43-52.

8. Jayaratne A. Application of a risk management system to improve drinking water safety. Water Health. 2008 Dec;6(4):547-57.

Mintz E, Bartram J, Lochery P, Wegelin M. Not just a drop in the bucket: expanding access to point-of-use water treatment systems. Am J Public Health. 2001 Oct;91(10):1565-70. 